\title{
Comparative assessment of the antibacterial efficacy of leaf extract obtained from Ficus benjamina L. (Moraceae) and its cultivars against Aeromonas sobria strain
}

\author{
Agnieszka Pękala-Safińska1, Halyna Tkachenko²*, Lyudmyla Buyun³ , Natalia Kurhaluk², \\ Ivan Gurnenko ${ }^{3}$, Vitaliy Honcharenko ${ }^{4}$, Andriy Prokopiv ${ }^{4,5}$ \\ ${ }^{1}$ National Veterinary Research Institute, Department of Fish Diseases, Puławy, Poland \\ ${ }^{2}$ Institute of Biology and Environmental Protection, Pomeranian University in Słupsk, Poland \\ ${ }^{3}$ M.M. Gryshko National Botanical Garden, National Academy of Sciences of Ukraine, Kyiv, Ukraine \\ ${ }^{4}$ Ivan Franko National University in Lviv, Lviv, Ukraine \\ ${ }^{5}$ Botanic Garden of Ivan Franko National University in Lviv, Lviv, Ukraine
}

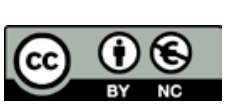

Article Details:

Received: $\quad$ 2021-02-17

Accepted: $\quad$ 2021-03-18

Available online: 2021-05-31

The present study is in vitro study to evaluate the antimicrobial activity of the ethanolic extracts derived from leaves of Ficus benjamina L. and its cultivars (Safari, Baroque, Amstel Gold, Reginald) against Aeromonas sobria to assess the possible use of this plant in preventing infections caused by this fish pathogen in aquaculture. Antimicrobial susceptibility of the tested Aeromonas sobria was performed by the Kirby-Bauer disc diffusion method according to the recommendations of the Clinical and Laboratory Standards Institute (CLSI). Our results revealed, that F. benjamina and its cultivars possessed antibacterial properties against Aeromonas sobria strain. The ethanolic extract obtained from leaves of $F$. benjamina 'Safari' exhibited the maximum antimicrobial activity against Aeromonas sobria (the mean of inhibition zone diameter was $26.19 \pm 1.32 \mathrm{~mm}$ ). Aeromonas sobria strain was susceptible to the F. benjamina 'Amstel Gold' (15.25 $\pm 1.25 \mathrm{~mm}$ ) and 'Reginald' (16.25 $\pm 1.10 \mathrm{~mm})$. Aeromonas sobria strain was the most resistant to $F$. benjamina $(12.5 \pm 0.80 \mathrm{~mm})$ and $F$. benjamina 'Baroque' $(13.63 \pm 0.75 \mathrm{~mm})$ leaf extracts. The results of this study provide a new perspective for the use of various Ficus species as medicinal plants to improve the antibacterial responses in aquaculture. Scanning electron microscopy has been employed to observe epicuticular wax structures which can be used to assure the correct identification of plant raw materials. Further studies including the use of other medicinal plants as food additives in aquaculture, the assessment of their antioxidant effects on various tissues of salmonids are in progress.

Keywords: Ficus benjamina L., Aeromonas sobria, antimicrobial activity, disc diffusion technique, ethanolic extracts

\section{Introduction}

At the current time, there are intense and active investigations into natural products with biocidal activities for fish (Galina et al., 2009). Plant-derived compounds act as a better antibacterial, antiviral, immunostimulant, and antistress effect in fish and shellfish aquaculture. For that reason, there has been considerable interest in the use of medicinal plants in aquaculture to provide safe and eco-friendly compounds for replacing antibiotics and chemical compounds as well as to enhance immune status and control fish diseases (Awad and Awaad, 2017). In addition to the immunostimulant properties, it has also been demonstrated that many medicinal plants are also able to have other positive effects on fish, such as the stimulation of fish growth, weight gain, and early maturation of cultured species (Galina et al., 2009;

\footnotetext{
*Corresponding Author: Halyna Tkachenko, Institute of Biology and Earth Sciences, Pomeranian University in Słupsk, Arciszewski Str. 22b, 76-200 Słupsk, Poland $\triangle$ tkachenko@apsl.edu.pl
} 
Biller-Takahashi and Urbinati, 2014; Newaj-Fyzul and Austin, 2015; Vallejos-Vidal et al., 2016).

In this study, attention focused on the genus Ficus L., a genus with diverse ethnobotanical uses in its geographical distribution range, has occupied an important place among plant genera applied for the treatment of a broad spectrum of diseases and disorders. Along with being an object of extreme interest for researchers during the last two centuries, Ficus has a long history of use by humans as a food source, in medicine, planting, and other industries and fields of human activity, partly owing to its great diversity and wide distribution range. Among popular ethnomedicinal uses of Ficus are treatments of skin damages, disorders of the digestive system and related organs, and parasitic infections. Besides these, the range of healing targets for particular Ficus species compiled from local medicines can be competitive with that of broad-spectrum traditional remedies (Berg and Wiebes, 1992; Cook and Rasplus, 2003; Berg and Corner, 2005). Among the pharmacological properties demonstrated for the compounds present in the genus Ficus are anticonvulsant, anti-inflammatory, analgesic, antimicrobial, antiviral, hypolipidemic, antioxidant, immunomodulatory, antiasthmatic, parasympathetic modulatory, estrogenic, antitumor, antiulcer, antianxiety, antihelmintic, analgesic, tonic, anti-diabetic, antipyretic, anti-inflammatory, antitussive, hepatoprotective activities, etc. (Ahmed and Urooj, 2010; Lansky and Paavilainen, 2011; Singh et al., 2011; Dangarembizi et al., 2012; Badgujar et al., 2014; Bunawan et al., 2014; Yadav et al., 2015). For all these reasons, plants belonging to the genus Ficus could be considered a priori as a good source of new natural compounds to treat, prevent, and control fish diseases in aquaculture.

Ficus benjamina L. also referred to as a weeping fig tree, is a multipurpose tree found in a large area including India, southern China, Southeast Asia, Malaysia, the Philippines, northern Australia, and the islands of the South Pacific (Riffle, 1998). It grows as a large evergreen shrub, up to $8 \mathrm{~m}$ tall, with nearly $10 \mathrm{~m}$ wide-spreading crown and drooping shoots with young slender twigs (Imran et al., 2014). It is one of the most popular indoor ornamental plants worldwide. The plant is well known due to its medicinal potential. Its latex and some fruit extracts are used by indigenous communities to treat skin disorders, inflammation, piles, vomiting, leprosy, malaria, nose diseases, and cancer besides the use as a general tonic. The plant is also used as an antimicrobial, antinociceptive, antipyretic, hypotensive, and antidysentery remedy. The leaves and twigs are used as insect repellants (Imran et al., 2014). The leaves, bark, and fruits of $F$ benjamina contain various bioactive constituents like cinnamic acid, lactose, naringenin, quercetin, caffeic acid, and stigmasterol (Sirisha et al., 2010). F. benjamina wood uses in aerobic biofiltration as a support medium for the treatment of Tequila vinasses (Marco Antonio et al., 2018).

In this study, we evaluated the antimicrobial activity of the ethanolic extracts of $F$. benjamina and its cultivars, i.e. F. benjamina 'Safari', 'Baroque,' 'Amstel Gold, 'Reginald' against Aeromonas sobria to evaluate the possible use of this plant in preventing infections caused by this fish pathogen in aquaculture. Given that standardization and quality control are essential analytical steps to assure the correct identification of plant raw materials to be used as plant-derived medicines, the micromorphology of $F$. benjamina leaf surfaces has been investigated with SEM procedure. The need for constant incorporation of leaf micromorphology in pharmacological investigations has been emphasized in some recent papers (Bilić et al., 2019; Khan et al., 2020).

The current study was conducted as a part of an ongoing project between the Institute of Biology and Earth Sciences (Pomeranian University in Słupsk, Poland), National Veterinary Research Institute (Puławy, Poland), M.M. Gryshko National Botanic Gardens of National Academy of Sciences of Ukraine (Kyiv, Ukraine), and Ivan Franko National University in Lviv (Lviv, Ukraine) undertaken in the frame of cooperation program aimed at assessment of medicinal properties of tropical and subtropical plants, cultivated in vitro.

\section{Material and methodology}

\section{Collection of plant material and preparing plant extract}

The leaves of F. benjamina and its cultivars (Safari, 'Baroque, Amstel Gold, Reginald) were sampled at National Botanic Garden, National Academy of Science of Ukraine (Kyiv, Ukraine), and Botanic Garden of Ivan Franko National University in Lviv (Lviv, Ukraine). The sampled leaves were brought into the laboratory for antimicrobial studies. Freshly sampled leaves were washed, weighed, crushed, homogenized in $96 \%$ ethanol (in proportion $1: 10$ ) at room temperature, and centrifuged at $3000 \mathrm{~g}$ for 5 minutes. Supernatants were stored at $-20^{\circ} \mathrm{C}$ in bottles protected with the laminated paper until required.

\section{Bacterial strains for antimicrobial activity assay}

Aeromonas sobria (K825) strain, originated from freshwater fish species such as common carp (Cyprinus 
carpio L.) and rainbow trout (Oncorhynchus mykiss Walbaum), respectively, was isolated in the Department of Fish Diseases, The National Veterinary Research Institute in Pulawy (Poland). Bacteria were collected from fish exhibiting clinical disorders. Each isolate was inoculated onto trypticase soy agar (TSA) (BioMérieux Polska Sp. z o.o.) and incubated at $27 \pm 2{ }^{\circ} \mathrm{C}$ for $24 \mathrm{hr}$. Pure colonies were used for biochemical identifications, according to the manufacturer's instructions, except the temperature of incubation, which was at $27 \pm 1{ }^{\circ} \mathrm{C}$. The following identification systems were used in the study: API 20E, API 20NE, API 50CH (BioMérieux Polska Sp. z o.o.). Presumptive Aeromonas isolates were further identified to the species level by restriction analysis of $16 \mathrm{~S}$ rDNA genes amplified by polymerase chain reactions (PCR) (Kozińska, 2007).

\section{Bacterial growth inhibition test of plant extracts by the disk diffusion method}

Antimicrobial susceptibility of the tested Aeromonas sobria was performed by the Kirby-Bauer disc diffusion method (1966) according to the recommendations of the Clinical and Laboratory Standards Institute (CLSI) (2014). Each inoculum of bacteria in the density of 0.5 Mc McFarland was cultured on Mueller-Hinton agar for $24 \mathrm{hr}$ at $28 \pm 2{ }^{\circ} \mathrm{C}$. Seven drugs representing different antimicrobial classes as quinolones, tetracyclines, sulphonamides, and phenols were used. After incubation, the inhibition zones were measured. Interpretation criteria have been adopted from that available for Aeromonas salmonicida (CLSI, 2006).

\section{Micromorphological leaf surface investigation}

Visualization of leaf surfaces micromorphology of Ficus benjamina was undertaken with scanning electron microscopy (SEM) technique. The dried leaf samples were sputter-coated with carbon in a vacuum universal post (VUP-5M) and platinum in a JEOL JFC-
1600 Auto Fine Coater. After then SEM analysis was carried out using a JEOL JSM-6700F scanning electron microscope at $15 \mathrm{kV}$ acceleration voltage in the high vacuum mode.

\section{Statistical analysis}

Statistical analysis of the data obtained was performed by employing the mean \pm standard error of the mean (S.E.M.). All variables were tested for normal distribution using the Kolmogorov-Smirnov test ( $p>0.05$ ). To find significant differences (significance level, $p<0.05$ ) between groups, the Kruskal-Wallis test by ranks was applied to the data (Zar, 1999). All statistical analyses were performed using Statistica 8.0 software (StatSoft, Poland). The following zone diameter criteria were used to assign susceptibility or resistance of bacteria to the phytochemicals tested: Susceptible (S) $\geq 15 \mathrm{~mm}$, Intermediate (I) $=10-15 \mathrm{~mm}$, and Resistant (R) $\leq 10 \mathrm{~mm}$ (Okoth et al., 2013).

\section{Results and discussion}

As can be seen from Figure 1, F. benjamina leaves are hypostomatic. Leaves possess paracytic stomata which are distributed regularly throughout the leaf surface between veins (Figure 1B). They are surrounded with a cuticular thickening that formed a rim (Figure 1C). The adaxial leaf surface is moderately undulate and pavement cells in the adaxial epidermis are difficult to recognize due to well-developed cuticle (Figure 1A). Nevertheless, epicuticular wax structures on the adaxial surface have not been observed. While the abaxial leaf surface has exhibited the deposition of small epicuticular wax plates (Figure 1C).

Results on in vitro antimicrobial activity assessment of ethanolic extracts derived from leaves of $F$ benjamina and its cultivars (Safari, Baroque, Amstel Gold, Reginald) against Aeromonas sobria strain expressed
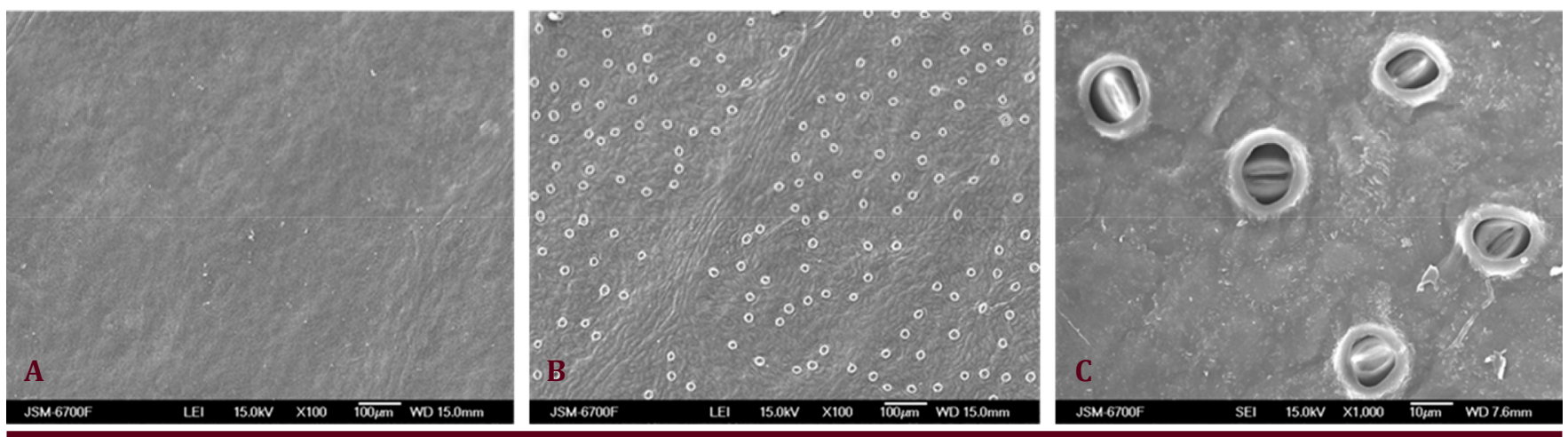

Figure 1

Scanning electron microscopy micrographs of adaxial (A) and abaxial (B, C) leaf surfaces of Ficus benjamina L. 


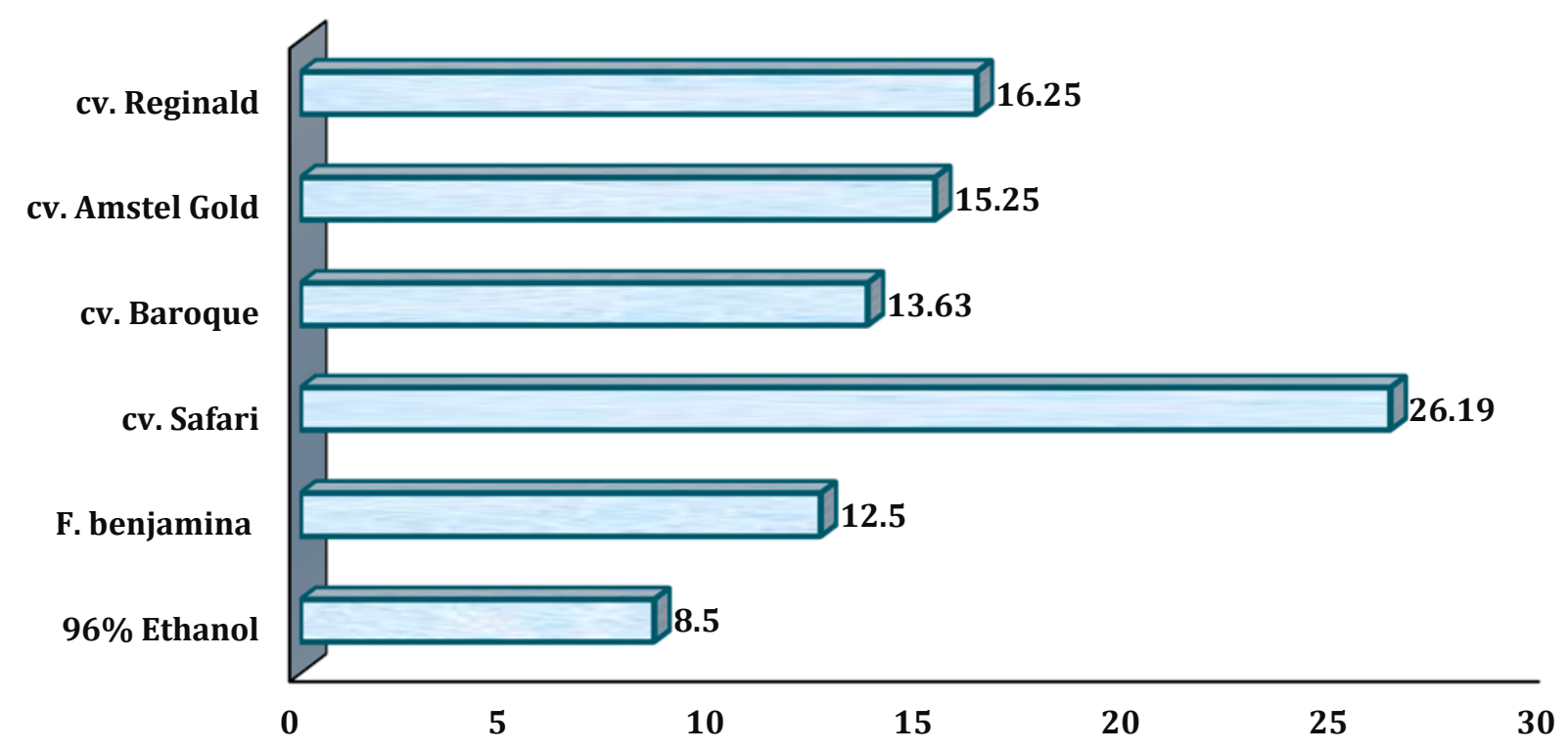

Figure 2 The mean inhibition zone diameters induced by ethanolic extracts derived from leaves of Ficus benjamina L. and its cultivars (Safari, Baroque, Amstel Gold, Reginald) against Aeromonas sobria strain (1000 $\mu \mathrm{L}$ inoculum) $(\mathrm{M} \pm \mathrm{m}, \mathrm{n}=8)$

as a mean of diameters of inhibition zone is presented in Figure 2.

Our results of the antimicrobial screening revealed, that F. benjamina and its cultivars possessed antibacterial properties against Aeromonas sobria strain. The ethanolic extract obtained from leaves of $F$. benjamina cv. Safari exhibited the maximum antimicrobial activity against Aeromonas sobria (the mean of inhibition zone diameters was $26.19 \pm 1.32 \mathrm{~mm}$ ). Aeromonas sobria strain was susceptible to the $F$. benjamina cv. Amstel Gold (15.25 $\pm 1.25 \mathrm{~mm}$ ) and cv. Reginald $(16.25 \pm 1.10 \mathrm{~mm})$. Aeromonas sobria strain was the most resistant to $F$. benjamina $(12.5 \pm 0.80 \mathrm{~mm})$ and F. benjamina cv. Baroque ( $13.63 \pm 0.75 \mathrm{~mm}$ ) leaf extracts (Figure 1).

In our previous studies, the therapeutic potential for the use of various plants of the Ficus genus in the control of bacterial diseases was evaluated against fish pathogens in vitro study with promising results (Tkachenko et al., 2016a,b,d, 2017a,b, 2018, 2019). Most ethanolic extracts obtained from Ficus spp. in our previous studies proved effective against the bacterial strain of Gramnegative $A$. hydrophila tested, with 10-12 mm zones of inhibition were observed. A. hydrophila demonstrated the highest susceptibility to $F$. pumila leaf extract. The highest antibacterial activity against A. hydrophila (200 $\mu \mathrm{L}$ of standardized inoculum) was displayed by $F$. benghalensis, F. benjamina, $F$. deltoidea, $F$. hispida, F. lyrata leaf extracts (Tkachenko et al., 2016a,d). Additionally, among various species of the Ficus genus exhibiting moderate activity against A. hydrophila
(400 $\mu \mathrm{L}$ of standardized inoculum), the highest antibacterial activity was displayed by $F$. benghalensis, F. benjamina, F. deltoidea, F. hispida, F. lyrata leaf extracts (Tkachenko et al., 2016c). Antibacterial properties of plant extracts have been by far the most studied bioactivity with potential applications in aquaculture systems (Reverter et al., 2014).

Moreover, in our previous study (Buyun et al., 2018), we have evaluated the in vitro effect of extracts obtained from leaves of $F$. benjamina and its cultivars on the oxidative stress biomarkers (carbonyl content of the oxidatively modified proteins, total antioxidant capacity) in the muscle tissue of the rainbow trout. Our results have shown that extracts obtained from leaves of F. benjamina 'Safari' and 'Reginald' cultivars decreased non-significantly the lipid peroxidation biomarker and the ketonic derivatives of oxidatively modified proteins levels in the muscle tissue. Furthermore, our results showed that extracts obtained from leaves of F. benjamina and its cultivars increased substantially the total antioxidant capacity in muscle tissue by $76.9 \%$ (F. benjamina), $66.9 \%$ (F. benjamina cv. Safari), $70.5 \%$ (F. benjamina cv. Baroque), $49.4 \%$ (F. benjamina cv. Amstel Gold), and $42.8 \%$ (F. benjamina cv. Reginald) ( $p<0.05$ ). The results of this study provide a new perspective on the use of various Ficus species as a medicinal plant to improve the antioxidant response of rainbow trout (Buyun et al., 2018).

It would be reasonable to suggest that these antimicrobial effects are determined by plant by-products, i.e. flavonoids. Indeed, the results of 
Imran et al. (2014) indicated that $F$. benjamina is a good source of components with high antibacterial activity. The extracts and fractions of stem, root, and leaves exhibited considerable antimicrobial activity against four bacterial and two fungal strains. The range of antimicrobial activity expressed as diameters of inhibition zone for stem was $10.5 \mathrm{~mm}$ (n-hexane) $22.83 \mathrm{~mm}$ (n-butanol). All the butanol fractions exhibited strong activity. The methanol extract (22.63 mm against Pseudomonas aeruginosa) and an n-butanolic fraction (22.83 against Bacillus subtilis) of stem showed substantial activity. The n-hexane, chloroform, and ethyl acetate sprouted a moderate value of diameters of inhibition zone, with maximum value disclosed by ethyl acetate $(16.88 \mathrm{~mm})$. The stem extract and fractions revealed the following order of antimicrobial potential against Bacillus cereus: methanolic $>$ n-butanolic $>$ ethyl acetate $>$ chloroform $>$ n-hexane (Imran et al., 2014).

F. benjamina also uses in the treatment of malaria which may be attributed to ursolic acid and lupeol. The study of Singh et al. (2020) emphasized the investigation of antiplasmodial activity of triterpenoids isolated from $F$. benjamina leaves. An unsaponified fraction of petroleum ether extract of plant leaves was subjected to silica gel column chromatography which led to the isolation of two known triterpenoids; namely ursolic acid and lupeol. These compounds were evaluated for antiplasmodial activity by schizont maturation inhibition assay using 3D7 Plasmodium strains. Both, ursolic acid and lupeol were found to exhibit significant antiplasmodial effect with an $\mathrm{IC}_{50}$ value of 18 and $3.8 \mu \mathrm{g} / \mathrm{ml}$, respectively (Singh et al., 2020).

Wanderley et al. (2018) have evaluated the anthelmintic potential of a protease purified from the latex of $F$. benjamina against Haemonchus contortus, a gastrointestinal nematode that is responsible for high mortality rates in ruminant herds. A cysteine protease $(\mathrm{FbP})$ inhibited both the development and escheatment of $H$. contortus larvae, with $50 \%$ effective concentrations of 0.26 and $0.79 \mathrm{mg} / \mathrm{mL}$, respectively. Thus, this cysteine protease from $F$. benjamina latex with anthelmintic activity against $H$. contortus could be a promising alternative for the development of products for use in parasite control programs (Wanderley et al., 2018).

Imran et al. (2014) showed that the HPLC analysis for the presence of phenolic acids permitted the identification of 5 phenolic acids, three in the stem, four in the root, and one in leaves. The total phenolic content (Folin-Ciocalteu) of the leaves of $F$. benjamina and $F$. luschnathiana were evaluated and screened by HPLC-DAD by Cruz et al. (2012). F. luschnathiana crude extract (CE) presented phenolic content higher than that of $F$. benjamina $(149.92 \pm 3.65$ versus 122.63 $\pm 2.79 \mathrm{mg}$ of GAE). Kaempferol (1.63 $\pm 0.16 \mathrm{mg} / \mathrm{g}$ dry weight of CE) and chlorogenic acid (17.77 $\pm 0.57 \mathrm{mg} / \mathrm{g}$ of butanolic fraction) were identified and quantified in F. benjamina. Additionally, rutin $(15.55 \pm 1.92 \mathrm{mg} / \mathrm{g}$ ) and quercetin $(3.53 \pm 0.12 \mathrm{mg} / \mathrm{g}$ ) were quantified in ethyl acetate and butanolic fractions, respectively. Sirisha et al. (2010) reported the presence of ursolic, $\alpha$-hydroxy ursolic, protocatechuic, and maslinic acids in Ficus species, while cinnamic and caffeic acids and quercetin have been reported in leaves, bark, and fruits of $F$. benjamina (Almahyl et al., 2003). All the detected phenolic acids are known to have antioxidant properties (Imran et al., 2014). So these phenolic acids may be responsible for the antibacterial activities of $F$. benjamina and its cultivars. In addition to their antioxidant activity, flavonoids also show good antibacterial activity against both Gram-positive and Gram-negative isolates (Daglia, 2012; Coppo and Marchese, 2014; Barbieri et al., 2017). Flavonoids can be divided into six subfamilies based on differences in their molecular backbone structure: flavonols, flavones, flavanols, flavanones, anthocyanidins, and isoflavonoids (Barbieri et al., 2017). They can inhibit DNA gyrase, cell membrane function, and bacterial energy metabolism (Cushnie and Lamb, 2005; Safavi et al., 2015). In recent years, flavonoids have been studied for their ability to interact with DNA helicases, proteins essential for DNA replication, repair, and recombination (Lohman et al., 2008), and to prevent dNTPs binding. In particular, Chen and Huang (2011), studied 4 flavonoids (galangin, kaempferol, quercetin, and myricetin at $10 \mu \mathrm{M}$ ) revealed that they capable of inhibiting the interaction of Klebsiella pneumoniae DnaB helicase with dNTPs. Huang et al. (2015) have demonstrated that some flavonoids (kaempferol and myricetin, at $35 \mu \mathrm{M}$ ) inhibit the PriA helicase activity of Staphylococcus aureus (Barbieri et al., 2017).

There are increasing awareness and general acceptability of the use of plant-derived medicines in today's medical practice. Nevertheless, it is believed that one of the disadvantages of herbal medicine is the lack of standardization and quality control profiles (Kunle et al., 2012).

One of the methods of pharmacognostic studies is micromorphological analysis, which makes it possible to ensure the identity of the raw material of medicinal plants (Khan et al., 2020). 
The study of foliar epidermal anatomy of some ethnobotanically important species of genus Ficus has been undertaken by Khan et al. (2011). Comprehensive morphological studies of Ficus species by light and scanning electron microscopy had been undertaking by Klimko and Truchan (2006).

We believe that comparative anatomical, micromorphological studies and bio-elemental analysis could be considered as an important part of a pharmacognostic investigation to ensure the correct taxonomic identification of the plant screened based on micromorphological and anatomical features.

\section{Conclusions}

The present study was carried out to provide evidence of the antibacterial potency of the extracts obtained from leaves of $F$. benjamina and its cultivars as a potential source of natural antimicrobial agents. F. benjamina disclosed substantial bioactivity, and this plant can be regarded as a potential source of antibacterial agents. In conclusion, the results of this study provide a new perspective for the use of various Ficus species as medicinal plants to improve the antibacterial responses in aquaculture. Further studies including the use of other medicinal plants as food additives in aquaculture, the assessment of their antioxidant effects on various tissues of salmonids are in progress.

\section{Acknowledgments}

This study was carried out during the Scholarship Program supported by The International Visegrad Fund in the Department of Zoology and Animal Physiology, Institute of Biology and Earth Sciences, Pomeranian University in Słupsk (Poland). We thank The International Visegrad Fund for supporting our study.

\section{References}

AHMED, F., UROOJ, A. 2010. Traditional uses, medicinal properties, and phytopharmacology of Ficus racemosa: a review. In Pharm. Biol., vol. 48(6), p. 672-681. https://doi.org/10.3109/13880200903241861

ALMAHYL, H.A., RAHMANI, M., SUKARP, M.A., ALI, A.A. 2003. Investigation on the chemical constituents of the leaves of Ficus elastica Roxb. and their antimicrobial activity. In Pertanika J. Sci. Tech., vol. 11, p. 57-63.

AWAD, E., AWAAD, A. 2017. Role of medicinal plants on growth performance and immune status in fish. In Fish Shellfish Immunol., vol. 67, p. 40-54. https://doi.org/10.1016/j.fsi.2017.05.034
BADGUJAR, S.B., PATEL, V.V., BANDIVDEKAR, A.H., MAHAJAN, R.T. 2014. Traditional uses, phytochemistry and pharmacology of Ficus carica: a review. In Pharm. Biol., vol. 52(11), p. 1487-1503. https://doi.org/10.3109/13880209.2014.892515

BARBIERI, R., COPPO, E., MARCHESE, A., DAGLIA, M., SOBARZO-SÁNCHEZ, E., NABAVI, S.F., NABAVI, S.M. 2017. Phytochemicals for human disease: An update on plant-derived compounds antibacterial activity. In Microbiol. Res., vol. 196, p. 44-68. https://doi.org/10.1016/j.micres.2016.12.003

BAUER, A.W., KIRBY, W.M., SHERRIS, J.C., TURCK, M. 1966. Antibiotic susceptibility testing by a standardized single disk method. In Am. J. Clin. Pathol., vol. 45(4), p. 493-496.

BERG, C.C., CORNER, E.J.H. 2005. Moraceae (Ficus). In Noteboom H.P. (ed.) Flora Malesiana, Ser. 1, vol. 17, Part 2. National Herbarium Nederland, Leiden, p. 1-730.

BERG, C.C., WIEBES, J.T. 1992. African fig trees and fig wasps. Koninklijke Nederlandse Akademie van Wetenschappen, Verhandelingen Afdeling Natuurkunde, 2de reeks, deel 89. North-Holland, Amsterdam, p. 298.

BILIĆ, V.L., STABENTHEINER, E., KREMER, D., DUNKIĆ, V., GRUBEŜIĆ, R.J., RODRÍGUEZ, J.V. 2019. Phytochemical and micromorphological characterization of Croatian populations of Erodium cicutarium. In Natural Product Communications, vol. 14(6), p. $1934578 \times 1985625$. https://doi.org/10.1177/1934578X19856257

BILLER-TAKAHASHI, J.D., URBINATI, E.C. 2014. Fish Immunology. The modification and manipulation of the innate immune system: Brazilian studies. In An. Acad. Bras. Cienc., vol. 86(3), p. 1484-1506.

BUNAWAN, H., AMIN, N.M., BUNAWAN, S.N., BAHARUM, S.N., MOHD NOOR, N.2014. Ficus deltoidea Jack: AReview on Its Phytochemical and Pharmacological Importance. In Evid. Based Complement. Alternat. Med., vol. 2014, p. 902734. https://doi.org/10.1155/2014/902734

BUYUN, L., TKACHENKO, H., MARYNIUK, M., KHARCHENKO, I., OSADOWSKI, Z., HONCHARENKO, V., PROKOPIV, A. 2018. In vitro evaluation of oxidative stress biomarkers in the muscle tissue of rainbow trout (Oncorhynchus mykiss Walbaum) exposed to leaf extract of Ficus benjamina L. and its cultivars. In Agrobiodiversity for Improving Nutrition, Health and Life Quality, vol. 2, p. 159-169. https://doi.org/10.15414/ agrobiodiversity.2018.2585-8246.159-169

CHEN, C.C., HUANG, C.Y. 2011. Inhibition of Klebsiella pneumoniae DnaB helicase by the flavonol galangin. In Protein J., vol. 30(1), p. 59-65. https://doi.org/10.1007/s10930-010-9302-0

COOK, J.M., RASPLUS, J.-Y. 2003. Mutualists with attitude: coevolving fig wasps and figs. In Trends in Ecology \& Evolution, vol. 18(5), p. 241-248.

COPPO, E., MARCHESE, A. 2014. Antibacterial activity of polyphenols. In Curr. Pharm. Biotechnol., vol. 15(4), p. 380-390. https://doi.org/10.2174/13892010150414 $\underline{0825121142}$ 
CUSHNIE, T.P., LAMB, A.J. 2005. Antimicrobial activity of flavonoids. In Int. J. Antimicrob. Agents, vol. 26(5), p. 343-356. https://doi.org/10.1016/j. ijantimicag.2005.09.002

DA CRUZ, R.C., AGERTT, V., BOLIGON, A.A., JANOVIK, V., ANRAKU DE CAMPOS, M.M., GUILLAUME, D., ATHAYDE, M.L. 2012. In vitro antimycobacterial activity and HPLC-DAD screening of phenolics from Ficus benjamina L. and Ficus luschnathiana (Miq.) Miq. leaves. In Nat. Prod. Res., vol. 26(23), p. 2251-2254. https://doi.org/10.1080/14786419.2011.650637

DAGLIA, M. 2012. Polyphenols as antimicrobial agents. In Curr. Opin. Biotechnol., vol. 23(2), p. 174-181. https://doi.org/10.1016/j.copbio.2011.08.007

DANGAREMBIZI, R., ERLWANGER, K.H., MOYO, D., CHIVANDI, E. 2012. Phytochemistry, pharmacology and ethnomedicinal uses of Ficus thonningii (Blume Moraceae): a review. In Afr. J. Tradit. Complement. Altern. Med., vol. 10(2), p. 203-212. https://doi.org/10.4314/ajtcam.v10i2.4

GALINA, J., YIN, G., ARDÓ, L., JENEY, Z. 2009. The use of immunostimulating herbs in fish. An overview of research. In Fish Physiol. Biochem., vol. 35(4), p. 669-676. https://doi.org/10.1007/s10695-009-9304-Z

HUANG, Y.H., HUANG, C.C., CHEN, C.C., YANG, K.J., HUANG, C.Y. 2015. Inhibition of Staphylococcus aureus PriA Helicase by Flavonol Kaempferol. In Protein J., vol. 34(3), p. 169-172.

https://doi.org/10.1007/s10930-015-9609-y

IMRAN, M., RASOOL, N., RIZWAN, K., ZUBAIR, M., RIAZ, M., ZIA-UL-HAQ, M., RANA, U.A., NAFADY, A., JAAFAR, H.Z. 2014. Chemical composition and Biological studies of Ficus benjamina. In Chem. Cent. J., vol. 8(1), p. 12. https://doi.org/10.1186/1752-153X-8-12

KHAN, K.Y., KHAN M.A., AHMAD, M., SHAN, G.M., ZAFAR, M., NIAMAT, R., MUNIR, M., ABBASI, A.M., SHAH, G.M., NIGMAT, S. 2011. Foliar epidermal anatomy of some ethnobotanically important species of genus Ficus L. In Journal of Medicinal Plants Research, vol. 5(9), p. 1627-1638.

KHAN, S.A., DASTAGIR, G., UL UZA, N., MUHAMMAD, A., ULLAH, R. 2020. Micromorphology, pharmacognosy, and bioelemental analysis of an important medicinal herb: Verbascum thapsus L. In Microscope Research \& Technique, vol. 83(6), p. 636-646. https://doi.org/10.1002/jemt.23454

KLIMKO, M., TRUCHAN, M. 2006. Morphological variability of the leaf epidermis in selected taxa of the genus Ficus L. (Moraceae) and its taxonomical implications. In Acta Soc. Bot. Pol., vol. 75, p. 309-324.

KOZIŃSKA,A.2007.Dominantpathogenicspeciesofmesophilic aeromonads isolated from diseased and healthy fish cultured in Poland. In J. Fish Dis., vol. 30(5), p. 293-301. https://doi.org/10.1111/j.1365-2761.2007.00813.x

KUNLE, O.F., EGHAREVBA, H.O., AHMADU, A.P. 2012. Standardization of herbal medicines A review. In International Journal of Biodiversity and Conservation, vol. 4(3), p. 101-112. https://doi.org/10.5897/IJBC11.163

LANSKY, E.P., PAAVILAINEN, H.M. 2011. Figs: the genus Ficus. In: Hardman R. (ed.) Traditional herbal medicines for modern times, vol. 9. CRC Press, Boca Raton, p. 1-357.

LOHMAN, T.M., TOMKO, E.J., WU, C.G. 2008. Non-hexameric DNA helicases and translocases: mechanisms and regulation. In Nat. Rev. Mol. Cell Biol., vol. 9(5), p. 391401. https://doi.org/10.1038/nrm2394

MARCO ANTONIO, G.Z., ANGÉLICA JULIETA, A.R., ESPERANZA, R.C., GERARDO, B., GERARDO, D.G., EDSON BALTAZAR, E.A.2018. Evaluation of Ficus benjamina wood chip-based fungal biofiltration for the treatment of Tequila vinasses. In Water Sci. Technol., vol. 77(5-6), p. 1449-1459. https://doi.org/10.2166/wst.2018.023

NEWAJ-FYZUL, A., AUSTIN, B. 2015. Probiotics, immunostimulants, plant products and oral vaccines, and their role as feed supplements in the control of bacterial fish diseases. In J. Fish Dis., vol. 38(11), p. 937-955. https://doi.org/10.1111/jfd.12313

OKOTH, D.A., CHENIA, H.Y., KOORBANALLY, N.A. 2013. Antibacterial and antioxidant activities of flavonoids from Lannea alata (Engl.) Engl. (Anacardiaceae). In Phytochem. Lett., vol. 6, p. 476-481. http://dx.doi.org/10.1016/j.phytol.2013.06.003

REVERTER, M., BONTEMPS, N., LECCHINI, D., BANAIGS, B., SASAL, P. 2014. Use of plant extracts in fish aquaculture as an alternative to chemotherapy: Current status and future perspectives. In Aquaculture, vol. 433, p. 50-61. https://doi.org/10.1016/j.aquaculture.2014.05.048

RIFFLE, R.L. 1998. The Tropical Look. Portland, Oregon: Timber Press, Inc.

SAFAVI, M., SHAMS-ARDAKANI, M., FOROUMADI, A. 2015. Medicinal plants in the treatment of Helicobacter pylori infections. In Pharm. Biol., vol. 53(7), p. 939-960. https://doi.org/10.3109/13880209.2014.952837

SINGH, A., MUKHTAR, H.M., KAUR, H., KAUR, L. 2020. Investigation of antiplasmodial efficacy of lupeol and ursolic acid isolated from Ficus benjamina leaves extract. In Nat. Prod. Res., vol. 34(17), p. 2514-2517. https://doi.org/10.1080/14786419.2018.1540476

SINGH, D., SINGH, B., GOEL, R.K. 2011. Traditional uses, phytochemistry and pharmacology of Ficus religiosa: a review. In J. Ethnopharmacol., vol. 134(3), p. 565-583. https://doi.org/10.1016/j.jep.2011.01.046

SIRISHA, N., SREENIVASULU, M., SANGEETA, K., CHETTY, C.M. 2010. Antioxidant properties of Ficus species, a review. In Int. J. Pharma Techn. Res., vol. 4, p. 2174-2182.

TKACHENKO, H., BUYUN,L., KASIYAN, O., TERECH-MAJEWSKA, E., HONCHARENKO, V., PROKOPIV, A., OSADOWSKI, Z. 2018. Preliminary in vitro screening of antibacterial activity of leaf extract from Ficus natalensis subsp. natalensis Hochst. (Moraceae) against fish pathogens. In Agrobiodiversity for Improving Nutrition, Health and Life Quality, vol. 2, p. 170-183. https://doi.org/10.15414/ agrobiodiversity.2018.2585-8246.170-183 
TKACHENKO, H., BUYUN, L., OSADOWSKI, Z., HONCHARENKO, V., PROKOPIV, A. 2017a. The antimicrobial efficacy of ethanolic extract obtained from Ficus benghalensis L. (Moraceae) leaves. In Agrobiodiversity for improving nutrition, health, and life quality, vol. 1, p. 438-445. http://dx.doi.org/10.15414/ agrobiodiversity.2017.2585-8246.438-445

TKACHENKO, H., BUYUN, L., OSADOWSKI, Z., TERECHMAJEWSKA, E., HONCHARENKO, V., PROKOPIV, A. 2017b. Comparative study of the antimicrobial efficacy of the ethanolic leaf extract of Ficus benghalensis L. (Moraceae) against bacterial fish pathogens. In Słupskie Prace Biologiczne, vol. 14, p. 209-228.

TKACHENKO, H., BUYUN, L., TERECH-MAJEWSKA E., OSADOWSKI, Z., SOSNOVSKYI, Y., HONCHARENKO, V., PROKOPIV, A. 2016d. In vitro antibacterial efficacy of various ethanolic extracts obtained from Ficus spp. leaves against the fish pathogen, Pseudomonas fluorescens. In Globalisation and regional environment protection. Technique, technology, ecology. Sci. eds T. Noch, W. Mikołajczewska, A. Wesołowska. Gdańsk, Gdańsk High School Publ., 2016, p. 265-286.

TKACHENKO, H., BUYUN, L., TERECH-MAJEWSKA, E., HONCHARENKO, V., PROKOPIV, A., OSADOWSKI, Z. 2019. Preliminary in vitro screening of the antibacterial activity of leaf extracts from various Ficus species (Moraceae) against Yersiniaruckeri.InFish.Aquat.Life,vol.27,p.15-26. https://doi.org/10.2478/aopf-2019-0002

TKACHENKO, H., BUYUN, L., TERECH-MAJEWSKA, E., OSADOWSKI, Z. 2016a. Antibacterial activity of ethanolic leaf extracts obtained from various Ficus species (Moraceae) against the fish pathogen, Citrobacter freundii. In Baltic Coastal Zone - Journal of Ecology and Protection of the Coastline, vol. 20, p. 117-136.

TKACHENKO, H., BUYUN, L., TERECH-MAJEWSKA, E., OSADOWSKI, Z. 2016b. In vitro antimicrobial activity of ethanolic extracts obtained from Ficus spp. leaves against the fish pathogen Aeromonas hydrophila. In Arch. Pol. Fish., vol. 24, p. 219-230. https://doi.org/10.1515/aopf-2016-0019
TKACHENKO, H., BUYUN, L., TERECH-MAJEWSKA, E., OSADOWSKI, Z. 2017c. Antibacterial screening of ethanolic extracts obtained from leaves of various Ficus species (Moraceae) against Citrobacter freundii. In Trudy VNIRO, vol. 167, p. 138-149.

TKACHENKO, H., BUYUN, L., TERECH-MAJEWSKA, E., OSADOWSKI, Z., SOSNOVSKYI, Y., HONCHARENKO, V., PROKOPIV, A. 2016c. The antimicrobial activity of some ethanolic extracts obtained from Ficus spp. leaves against Aeromonas hydrophila. In Trudy VNIRO, vol. 162, p. 172-183.

VALLEJOS-VIDAL, E., REYES-LÓPEZ,F., TELES, M., MACKENZIE, S. 2016. The response of fish to immunostimulant diets. In Fish Shellfish Immunol., vol. 56, p. 34-69. https://doi.org/10.1016/j.fsi.2016.06.028

WANDERLEY,L.F.,SOARES,A.M.D.S.,SILVA,C.R.E.,FIGUEIREDO, I.M., FERREIRA, A.T.D.S., PERALES, J., MOTA, H.R.O., OLIVEIRA, J.T.A., COSTA JUNIOR, L.M. 2018. A cysteine protease from the latex of Ficus benjamina has in vitro anthelmintic activity against Haemonchus contortus. In Rev. Bras. Parasitol. Vet., vol. 27(4), p. 473-480. https://doi.org/10.1590/S1984-296120180070

YADAV, R.K., NANDY, B.C., MAITY, S., SARKAR, S., SAHA S. 2015. Phytochemistry, pharmacology, toxicology, and clinical trial of Ficus racemosa. In Pharmacogn. Rev., vol. 9(17), p. 73-80. https://doi.org/10.4103/0973-7847.156356

ZAR, J.H. 1999. Biostatistical Analysis. $4^{\text {th }}$ ed., Prentice-Hall Inc., Englewood Cliffs, New Jersey. 